\title{
A theoretical exploration of consumer engineering: implicit contracts and market making
}

Book or Report Section

Accepted Version

Godley, A. and Heron, K. (2019) A theoretical exploration of consumer engineering: implicit contracts and market making. In: Logemann, J., Cross, G. and Köhler, I. (eds.) Consumer Engineering, 1920s-1970s. Worlds of Consumption. Palgrave Macmillan, pp. 63-75. doi: https://doi.org/10.1007/978-3-03014564-4_4 Available at http://centaur.reading.ac.uk/84145/

It is advisable to refer to the publisher's version if you intend to cite from the work. See Guidance on citing.

Published version at: https://link.springer.com/chapter/10.1007/978-3-030-14564-4_4

To link to this article DOI: http://dx.doi.org/10.1007/978-3-030-14564-4_4

Publisher: Palgrave Macmillan

All outputs in CentAUR are protected by Intellectual Property Rights law, including copyright law. Copyright and IPR is retained by the creators or other copyright holders. Terms and conditions for use of this material are defined in 
the End User Agreement.

www.reading.ac.uk/centaur

\section{CentAUR}

Central Archive at the University of Reading

Reading's research outputs online 


\section{A Theoretical Exploration of Consumer Engineering: Implicit Contracts and Market Making}

Andrew Godley and Keith Heron

The growing literature exploring the emergence of modern marketing has concentrated on the periodization of different marketing techniques coming into usage, the retailing of different product categories, the internationalization of retail formats, and advertising practices. ${ }^{1}$ But recent research has begun to focus on deliberate attempts to elicit consumer spending on novel products by firms and marketing specialists. This more recent literature explores how specialists, in particular designers and market researchers, in the middle decades of the twentieth century began to move away from a product-focused approach to one that placed the consumer at the center of marketing initiatives. This development was also associated with the move away from marketing as simply a promotional activity toward strategic marketing instead. Now marketing management informed the entire organization of activities within the firm. ${ }^{2}$

The near paradox of this mid-century movement was that while its adherents were intent on the primacy of consumer interests, consumer agency was viewed with suspicion. In 1952, the German-American market researcher Alfred Politz emphasized that "consumers do not know what they want and why they act." ${ }^{3}$ With consumers so resistant to the active search for answers to their problems, specialists had to step in to diagnose and solve their problems for them. ${ }^{4}$ These specialist market researchers and product designers developed tools and techniques to elicit the explication of previously unarticulated consumer preferences. This was consumer engineering. The historical debates on consumer engineering, on whether or not it was beneficial to or exploitative of consumers, are summarized elsewhere in this volume. This chapter aims to use economic reasoning to explain why consumer engineering was so successful. 
From a theoretical perspective, this description of the relationship between producers and consumers is one that is characterized by information asymmetries. The sellers have information about the product that the buyers do not possess. Producers believe they have a product that will solve a consumer problem, but consumers typically do not know whether the product will solve their problem or not. Using information economics theory and exploring the implications of information asymmetries, this article will explore a theoretical explanation for the rise and significance of consumer engineers in the mid-twentieth century, suggesting why consumer engineering became significant at a certain time and in certain sectors rather than others.

The result of this theoretical exercise is the suggestion that producers of novel and complex consumer goods, especially of durable goods, have to engage in market-making innovation as well as product innovation. Market-making innovation describes a set of contractual (or more often quasi-contractual) agreements designed to overcome consumers' reluctance to purchase a product. This reluctance to purchase is driven not by the product, but instead by the nature of the transaction. Transactions between consumers and producers can be very simple. But they can also become very complicated. One of the principal drivers of transactional complexity is the presence of information asymmetries.

\section{Setting out the Problem of Information Asymmetries: Moral Hazard and Adverse Selection in Effects in Consumer Markets}

The transactional relationship under consideration is between firms and consumers. ${ }^{5}$ Firms sell novel products to consumers. Consumers buy these novel products, about which they have little information, from firms. Under such conditions of uncertainty, consumer purchases are decisions made on the basis of crude estimates of expected future utility. ${ }^{6}$ There is a risk such estimates 
may turn out to be wildly inaccurate. Consumers in fact only acquire sufficient information to make an informed judgment about the utility of a purchased novel product at some point after the formal completion of the contract, meaning these transactions share characteristics of incomplete, open-ended contracts and their associated risks. Producers may seek to disseminate information to overcome such risks, but consumers are unlikely to take such information at face value, as producers may be less than fully transparent in order to complete and profit from the transaction.

This is not the case for all novel consumer goods. For many new products, consumers are well placed to be able to test the firm's claims because for many products, "search goods" in Nelson's terminology, consumers can sample or test goods before purchase. ${ }^{7}$ Nelson differentiated search goods from others, which are sufficiently complex in nature that consumers are unable to gain sufficient information prior to purchase, which he called "experience goods." Transactions involving the latter possess similar characteristics to open-ended, incomplete contracts because novel experience goods are acquired in faith by consumers. Only through actually experiencing them after purchase is the consumer genuinely able to judge whether the product has met ex ante expectations. Substantial experimental evidence from behavioral economists conclusively shows that poorly informed consumers facing complex products typically prefer not to purchase the product, rather than run the risk of making an incorrect decision. ${ }^{8}$ Economists call this risk to transactions from the relative ignorance of one party the adverse selection effect.

Nelson went on to identify a class of goods where consumers would not even be able to judge the utility after experiencing them: credence goods. ${ }^{9}$ For some quasi-open-ended transactions there is also the additional risk of moral hazard, where one party has the power to 
exploit the other without being detected, so where sellers can exploit buyers' gullibility. This leads to what Akerlof described as the "lemons" problem. ${ }^{10}$ In markets for credence goods characterized by information asymmetry, where the seller possesses more information than the buyer and where the buyer suspects that the seller may act opportunistically, the buyer will insist on a discount in the price to reflect the cost of insuring against their possible exploitation by the seller (or of the purchase turning into a "lemon," the American slang expression for dud cars. Without such price cuts consumers will withdraw from the market as the risk of them losing out to opportunistic sellers appears too great. In some markets the reduction in price demanded by consumers to insure them against the risks of moral hazard may be easily absorbed or passed on to suppliers. But in markets characterized by very high sunk costs, producers may not be able to pay the consumers' implicit insurance premium. To overcome such a strong propensity to consumer withdrawal, producers must invest in developing communication channels not only to disseminate relevant information about the product itself but also to convince consumers of their trustworthiness. ${ }^{11}$ The penalty of continued consumer suspicion of opportunistic producer behavior is lower prices, lower profits, and even market breakdown.

The probability that an experience good will become a credence good depends on the extent of the threat of moral hazard. For example, there are several kinds of experience goods that spur repeat demand; the products are consumed typically shortly after purchase, leading to further repeat purchases, subject to some satisfaction threshold being met. Consumers here are neither able to consume at the point of purchase (like most services) nor to sample before purchase (like search goods), but they are able to benefit from the information about the product generated by their previous purchases. The risks of novelty and the dependence on the 
producer's promise are not eradicated, but are modified to one where producers commit to ensure future purchases are consistent with previous ones.

For novel durable goods, however, consumers are more dependent on an entrepreneur's promise because the transactions are not repeat purchases (and so consumers possess no information from previous purchases), but also because once a durable good has been purchased, consumers have less incentive to continue sampling and testing alternatives thereafter. Consumer durables like computers or automobiles might be typical of these products. Furthermore, consumer durables are typically more expensive and are treated as quasi-investment goods. The possibility of a bad purchase therefore represents a higher long-term risk to consumer utility because of the time required before the expense can be fully amortized and the product replaced.

Table 1. Moral hazard, adverse selection, and the risk of consumer withdrawal

About here

Table 1 summarizes this first step of setting out the problem posed by information asymmetries. It illustrates that many transactions for novel goods and services are unaffected by either moral hazard or adverse selection effects, and so face minimal risk of consumer withdrawal. For 
example, when both adverse selection and moral hazard effects are low, in Box 1 (with novel search goods like clothing perhaps), consumers are sufficiently informed to pursue their own self-interest and fully commit to transactions. In Box 2, low product complexity means minimal risk of adverse selection effects, but the open-ended nature of the contract exposes consumers to the risk of moral hazard. Entrepreneurial entry into these types of markets (domestic construction services perhaps) would have to devise contractual strategies to avoid lemon-style insurancerelated discounts (through stage payments perhaps).

In some markets for complex experience goods, Box 3, consumers face the risk of adverse selection (it is too complex for them to know ex ante whether the product will meet expectations), but consumption is sufficiently coincident with the moment of purchase to make the risk of moral hazard minimal. These markets might be composed of nondurable goods and services. In order to overcome the risk of complexity, entrepreneurs may seek to build incrementally on existing products and services, thus enabling consumers to draw comparisons either from their own or others' previous transactions.

For entrepreneurs engaged in markets like Box 4, where entrepreneurs are introducing novel, complex, non-incremental durable goods, consumers in the target market possesses little relevant information and have little prospect of independently accessing such information so as to make an informed decision. There is therefore a high risk of adverse selection effects influencing consumer reception. Moreover, because consumers have to pay up front, but will have open-ended requirements, there is a strong risk of moral hazard. Such markets, often for novel, high-tech durable products with high intellectual property content, for instance, are a common feature of the entrepreneurship literature. ${ }^{12}$ Yet focusing on the characteristics of such markets from the consumer's perspective should lead to the conclusion that without appropriate 
market-making innovations, these are markets with a high risk of consumer withdrawal and so high rates of entrepreneurial failure regardless of the merits of the novel product itself.

\section{Producer Response: Market-Making Innovation and Implicit Contracts}

Nelson's focus on the different properties of consumer goods is helpful because it indicates how producers might respond with different advertising strategies when engaging with risk-averse consumers in transactions characterized by varying degrees of information asymmetries. While this was an advance on Akerlof (who, as Stiglitz reminds us, ignored the desire of producers to supply more information ${ }^{13}$ ), for the purposes of this article, Nelson's typology does not go far enough in explaining the difficulties facing entrepreneurs in responding to such information asymmetries. Indeed, there is nothing in Nelson's analysis that necessarily leads to an entrepreneur having to invest in a market-making response. Alternative institutional solutions could easily be envisaged (standards, regulations, independent arbiters, etc.) to overcome the problems to such transactions caused by information asymmetries. ${ }^{14}$ To understand why in most consumer goods markets it is producers who take on the role of reducing the risk of consumer withdrawal from the threats of adverse selection and moral hazard rather than any other party to the transaction, it is important to explain why consumers find it so difficult to specify their wishes in advance of purchasing a product.

\section{Overcoming Costly Pre-purchase Specification with Credible Commitments and Implicit Contracts for Novel Products}

Another way to conceptualize Nelson's demarcation between credence, experience, and search goods is to understand that when consumers are unable to specify their requirements prior to 
purchase, they will only be able to make an informed judgment of a product's utility after experiencing it. Consumers are able to assess search goods, the look and feel of the fabric, for example, and so acquire sufficient information about the good's likely utility before they purchase it. For credence and experience goods, by contrast, making such an assessment is impossible.

It is this inability to specify requirements before a purchase that so powerfully demarcates consumer demand from business demand for novel complex products. Businesses typically have a much greater understanding of the specification required for any particular new product and so business-to-business markets are often characterized by tenders and other sorting techniques to ensure better matches between buyer and seller. ${ }^{15}$

In the absence of clear specification from consumers, producers engage in some guesswork in order to better identify more exactly what it is that consumers desire but are unable to articulate. Producers may invest in market and consumer research to acquire partial support for their decisions. But no market research can provide perfect information, and so, in the end, producers have to opt for a particular product or design with less than perfect information about consumer desires. ${ }^{16}$ An entrepreneur making investment decisions in the face of just such an absence of consumer specifications is what Casson describes as exercising entrepreneurial judgment. ${ }^{17}$ It is this adoption of specific techniques by producers (often using specialist assistance) to better understand unarticulated consumer desires that historians have discussed as consumer engineering.

Having made their decision, producers have to communicate with their target audience about their particular novel product. But given that the real underlying consumer demand factors remain unarticulated, producers engage in communicating with consumers through tacit 
information like branding, logos, and other forms of product and corporate imagery, using vehicles such as advertising, sponsorship, public relations, and so on. Producers invest in such intangible information with the aim of leading consumers to recognize congruence between their unarticulated desires and what the firms are offering.

Producers of complex consumer goods therefore have to communicate with prospective consumers in order to convince them that the particular complex product is the solution to consumers' problem. But they have to do so in such a way that overcomes any reluctance to deal with complexity (adverse selection) and mistrust (moral hazard). This is market making. What makes it particularly difficult is that consumers are so unwilling to prespecify their requirements, that producers have to communicate solutions to consumers without articulating what are, in effect, quasi-contractual commitments.

The need for innovation in market making is therefore the outcome not of information asymmetries per se, but rather of the evidently very high costs to consumers of articulating more clearly their required specification pre-purchase. If producers found market-making more costly, then consumers would have a stronger incentive to specify their own requirements and then invest in a search for the most suitable providers. Such a market, like most business-to-business markets, would involve much reduced marketing costs, but much greater specification and search costs. Given the expense of market-making innovations like brands and reputations, it is reasonable to infer that consumers find it very costly to engage in any rigorous specification process. It is not so much that consumers "do not know what they want" (Politz) but that they discover that it is too expensive for them to find out.

Producers therefore have to provide sufficient relevant information to consumers more cheaply than consumers can discover it themselves. ${ }^{18}$ Moreover, it is firms that typically have the 
stronger incentive to resolve the risk of consumer withdrawal rather than consumers because firms' investments in sunk costs associated with production are significantly greater than any individual consumer's search costs. It is producers, therefore, that will invest in consumer engineering and other market-making strategies in order to make the markets for complex consumer goods work to all parties' satisfaction. When consumers typically do invest in prepurchase specification (for example, in self-designed house construction), there is much less incentive for producers to invest in brand creation (house builders, to continue the example, merely tender bids on price and quality).

In some consumer goods sectors, then, typically complex durable goods, where repeat purchases are rare, amortization costs are high, and consumers find pre-purchase specification very costly, producers face the strongest incentive to provide intangible product-specific information to consumers. Firms see real economic benefit to investing in consumer engineering and other market-making innovations. If consumers believe the intangible information offered by producers, the risks and hence the costs to contracting are reduced, and so consumers will transact and they too will enjoy the economic benefits of the transaction.

Such market-making solutions involve by definition the ability to meet a consumer's unarticulated, open-ended requirements and so require a firm to go beyond the explicit contract of exchange - transferring the rights to a good for a given price - to an implicit contract, where the producer communicates to the consumer that it will meet all their product-associated demands, whether understood at the moment of transaction or not, whether codified or not, and until some point in the future when consumer uncertainty falls away approximately to zero. Such a commitment to unspecified consumer requirements therefore represents unfunded guarantees to future expectations. Implicit contracts are costly but necessary market-making innovations. 
Okun defined implicit contracts as "invisible handshakes" or "arrangements that are not legally binding but that give both sides incentives to maintain the relationship." ${ }^{\prime 19}$ Substantial anecdotal or partial evidence of the pervasiveness of implicit contracts can be drawn from a variety of contexts in which relationship is preferred to contract. Examples occur in the business history literature on complex infrastructure projects, ${ }^{20}$ in the international management literature on German and Japanese corporate governance systems, ${ }^{21}$ and in the cross-cultural management literature on Chinese managers' decision-making, ${ }^{22}$ to list but a few.

The economic literature on implicit contracts makes clear, however, that markets so characterized are only able to function in the presence of supportive social norms. The most significant norm to be observed in experimental data is reciprocity. ${ }^{23}$ Reciprocity's importance in the behavioral economics literature derives from its ability to enable markets characterized by implicit contracts to function. It overcomes what Avner Greif has called "the fundamental problem of exchange. ${ }^{24}$ But this observation implies that a transactional relationship between entrepreneurs and consumers based on implicit contracts exhibits more similarities with a "prisoner's dilemma" view of the world than does the conventional understanding of price-taking free markets. Credible and long-term commitments to repeated exchange introduce significant constraints on both parties' freedom of action, with consumer engineering characterized by producer promises to consumers. When this marketing strategy succeeds, it is because consumers are able to judge from the evidence of the transaction that the producer has kept the promise. The principle of reciprocity then leads consumers to keep on purchasing and producer reputation is enhanced. On the other hand, should consumers detect from the evidence of consuming that producers are reneging, trust will break and the transactional relationship will fail. 
Implicit contracts have been particularly influential in the economics of the labor market, where the empirical observation of lower-than-expected levels of volatility in employment and wages over the course of a business cycle has been explained by "the hypothesis that contract wages embody implicit payments of insurance premiums by workers in favourable states of nature and receipts of indemnities in unfavourable states." 25 The equivalent of this wage rigidity in labor markets is price rigidity in consumer markets. The literature here emphasizes that riskaverse consumers interpret any change in price or quality that appears to favor producer interests as producer opportunism, and so producers face a strong incentive to maintain price and quality to avoid consumer boycotts. ${ }^{26}$ Once "the firm draws a clientele with attractive implicit contracts, any deviation unfavourable to consumers is seen as a violation of these contracts." 27 The strongest empirical support for this is provided by Young and Levy's excellent analysis of Coca Cola's seventy years' persistence with price rigidity, where the real price of Coca Cola was held almost constant for over seventy years. There is also Godley's interpretation of Singer's enormous investment in its international sales organization. Neither the cheapest nor technologically the best sewing machine, Singer was nevertheless able to enjoy a dominant global market position for several decades. ${ }^{28}$

To sum up, the first difficulty facing producers of novel complex durables is communicating to inarticulate consumers that such goods might meet their needs. Because most complex durables possess strong elements of basic multifunctionality, it is difficult for producers to signal likely post-purchase usage to potential consumers through conventional promotion strategies. Product complexity and consumer inability to pre-specify requirements suggest that an appropriate market-making solution to overcome the risk of adverse selection would be for an entrepreneur to invest in signaling mechanisms to disseminate information that allows consumers 
to judge how they might use the product. Historians research on consumer engineering could here focus on the nature of signaling mechanisms adopted by such producers.

The second difficulty relates to the open-ended nature of transactions. The explicit contract is a spot transaction (or a near-spot transaction in cases of installment purchases). But consumers will be aware of the risk of moral hazard, as producers simply may not keep promises. For novel durable goods, producers may initially offer attractive servicing and repair terms but subsequently change terms, for example. Entrepreneurs seeking to overcome consumer propensity to withdraw because of the risk of moral hazard would therefore need to make credible commitments not to change service conditions in ways that might adversely affect consumers. But because consumers' future requirements remain unspecified at the point of transaction, such a commitment must be made through an implicit contract.

It follows that if implicit contracts are the preferred solution to overcoming the threat of consumer withdrawal in markets for complex consumer goods, entrepreneurs will need to invest in market-making innovations that reduce the risks to consumers of adverse selection and moral hazard. Historians of marketing might here want to explore the relationship between product design and contractual design to better explain the significance of the nature of the contractual transaction as a market-making innovation.

The most complete market-making response would be a comprehensive presales demonstration and after-sales service that met all information requirements for consumers of novel durables, much as has been described for Singer. ${ }^{29}$ Such an investment would be hugely costly for entrepreneurs, but it would signal a credible, market-making commitment to elicit consumer trust at the market's point of entry. This scenario would represent the ultimate and most expensive example of consumer engineering. 
Given the expense associated with such a market-making innovation, entrepreneurs might simply pass on the costs of after-sales services to consumers in the form of an explicit list of prices for a variety of services. ${ }^{30}$ But charging the market rate for after-sales services opens up the possibility of third parties establishing themselves as competing sources of such services. In the long run, competition in the provision of aftersales service is unlikely to impact firm strategy, but at the point of market entry where the need to elicit trust with consumers is the key to successful market-making, competition in after sales service may undermine the credible commitments needed for the relationship between entrepreneur and consumer to begin. Thus, producers will prefer to subsidize their after-sales services and so deter competitor entry. Because the cost of such a subsidy has to come from product revenues, premium pricing strategies have to be employed by producers. Otherwise the subsidy for market-support services is not viable. The provision below-cost of after-sales support and advice to consumers of complex durables should therefore overcome much of the risk of potential consumer withdrawal. ${ }^{31}$ The implication is that historians of consumer engineering need also to take full account of producers' pricing strategies as another element of the relationship with consumers unable or unwilling to articulate their desires.

\section{Conclusion}

This discussion of the theory of implicit contracts and market-making takes as its point of departure theoretical insights drawn from information economics about the consequences for information asymmetries in market relationships and the high probability for these to lead to market failure of some sort. The chapter then suggests that adapting game theory insights from "prisoners' dilemma"-type scenarios suggests that the solution to such complex transactions lies 
in producers cultivating consumers' trust in their ability to solve consumers' problems. This insight can readily be applied to the rapid growth of consumer engineering during the middle decades of the twentieth century. This was the period of the consumer revolution, and the introduction of many novel, but complex consumer goods. But because consumers did not articulate their desires or pre-specify their requirements, it fell to producers to communicate the benefits of these novel products and why they would solve consumer problems. The criticism from consumer engineers of the time was that consumers "do not know what they want" (Politz). But the conclusion of this theoretical introduction would be that a better interpretation of consumer behavior was that consumers discovered that it was too costly for them to decide what they wanted.

Marketing materials shifted during the early decades of the twentieth century from being dominated by explicit product information to growing use of imagery and other forms of tacit information. As the twentieth century progressed, so producers increasingly moved to place consumers at the center of their marketing initiatives. Indeed, as the concept of strategic marketing emerged, so consumer requirements, rather than engineering constraints, became increasingly central to product design. Consumer engineers like Politz therefore had to develop tools and techniques to both identify consumer desires and then persuade firms to adapt their offerings in order to make these markets function optimally.

\footnotetext{
${ }^{1}$ Andrew Godley and Haiming Hang, "Collective Financing among Chinese Entrepreneurs and Department Store Retailing in China," Business History 58, no. 3 (2016): 364-77; Andrew Godley and Alessandra Tessari, "Made in Italy. Made in Britain. Quality, Brands and Innovation in the European Poultry Market, 1950-1980," Business History 56, no. 7 (2014): 1057-83;
} 
Andrew Godley and Haiming Hang, "Globalization and the Evolution of International Retailing: a comment on Alexander's “British Overseas Retailing, 1900-1960," Business History 54, no. 4 (2012): 529-41; Andrew Godley and Bridget Williams, "Democratizing Luxury and the Contentious 'Invention of the Technological Chicken' in Britain,” Business History Review 83, no. 2 (2009): 267-90.

${ }^{2}$ D. G. Brian Jones and Mark Tadajewski, eds., The Routledge Companion to Marketing History (Abingdon, 2016); and Köhler, Ingo; Logemann, Jan, Towards Marketing Management: German Marketing in the 19th and 20th Centuries, S. 371-88.

${ }^{3}$ Quoted by Jan Logemann in chap. 2 of the present volume.

${ }^{4}$ Andrew Godley and Mark Casson, “'Doctor, Doctor...' Entrepreneurial Diagnosis and Market Making," Journal of Institutional Economics 11, no. 3 (2015): 601-21.

5 This section is adapted from Andrew Godley, "Entrepreneurial Opportunities, Implicit Contracts and Market Making for Complex Consumer Goods," Strategic Entrepreneurship Journal 7, no. 4 (2013): 273-87.

${ }^{6}$ For the purposes of theory building, we are ignoring state intervention, warranty provision, comparison web-sites or other institutional innovations to overcome the threat of opportunistic behaviour in open-ended contracts in this section. Equally the focus is on goods rather than services, where consumption is mostly simultaneous with production, and so where transactions are mostly spot rather than sharing the open-ended characteristics emphasised here.

${ }^{7}$ See Philip Nelson, Advertising as Information. Journal of Political Economy 82, no. 4 (1974): 729-45.

${ }^{8}$ Godley, "Entrepreneurial Opportunities" discusses this. This seemingly counter-intuitive level of risk aversion shown by consumers in laboratory experiments conforms exactly with 
McCloskey's interpretation of why some English regions failed to adopt enclosure methods during the Agricultural Revolution. See Dierdre McCloskey, “The Enclosure of Open Fields: Preface to a study of its impact on the efficiency of English agriculture in the eighteenth century," Journal of Economic History, 32 (March 1972): 15-35.

${ }^{9}$ See Uwe Dulleck, Rudolf Kerschbamer, and Matthias Sutter, "The Economics of Credence Goods: An Experiment on Role of Liability, Verifiability, Reputation, and Competition,” American Economic Review 101 (April 2011): 530-59, for an excellent recent review.

${ }^{10}$ George A. Akerlof, “The Market for 'Lemons': Quality Uncertainty and the Market Mechanism," Quarterly Journal of Economics 84, no. 3 (1970): 488-500.

${ }^{11}$ See Koehler in this volume.

${ }^{12}$ See Gary Dushnitsky and Dovev Lavie, "How Alliance Formation Shapes Corporate Venture Capital Investment in the Software Industry: A Resource-Based Perspective," Strategic

Entrepreneurship Journal 4, no. 1 (2010): 22-48; Albrecht Enders et al., "The Long Tail of Social Networking: Revenue Models of Social Networking Sites. European Journal of Management 26, no. 3 (2008): 199-211.

${ }^{13}$ Joseph E. Stiglitz, "The contributions of the economics of information to twentieth century economics," Quarterly Journal of Economics 115 no. 4 (2000), p. 1452.

${ }^{14}$ Richard N. Langlois, "The Vanishing Hand: The Changing Dynamics of Industrial

Capitalism," Industrial and Corporate Change 12, no. 2 (2003): 351-85; Christian

Kleinschmidt, "Comparative consumer product testing in Germany," Business History Review

\section{4, no. 1 (2010): 105-124.}

${ }^{15}$ Obviously these are points on a spectrum rather than separate categories of behaviour. IBM's position of dominance in the business machine market for decades was based on the tag-line, "No one was ever fired for buying IBM," indicating that where information asymmetries arise in 
B2B markets, a similar pattern of behaviour to that described here for consumer markets emerges.

${ }^{16}$ Brian K. Orme, Getting Started with Conjoint Analysis: Strategies for Product Design and Pricing Research (Madison, WI, 2006), chap. 2.

${ }^{17}$ See Mark Casson The Entrepreneur: An Economic Theory (Cheltenham, 1982); Mark Christopher Casson, "Entrepreneurship and the Theory of the Firm, Journal of Economic Behaviour and Organisation 58, no. 2 (2005): 327-48. For historical applications, see Mark Casson and Andrew Godley, "Entrepreneurship and Historical Explanation," in Youssef Cassis and Ioanna Pepelasis Minoglou, eds., Entrepreneurship in Theory and History (Basingstoke, 2005); and Mark Casson and Andrew Godley, "Revisiting the Emergence of the Modern Business Enterprise: Entrepreneurship and the Singer Global Distribution System,” Journal of Management Studies 44, no. 7 (2007): 1064-77.

${ }^{18}$ Firms obviously gain from economies in pooling common characteristics of consumer demand specifications.

${ }^{19}$ Arthur M. Okun, Prices and Quantities: A Macroeconomic Analysis (Washington, DC, 1981), 49-50.

${ }^{20}$ Maria Eugénia Mata, “The Role of Implicit Contracts: Building Public Works in the 1840s in Portugal,” Business History 50, no. 2 (2008): 147-62.

${ }^{21}$ Tim Jenkinson and Colin Mayer, “The Assessment: Corporate Governance and Corporate Control," Oxford Review of Economic Policy 8, no. 3 (1992): 1-10.

22 John L. Graham and N. Mark Lam, “The Chinese Negotiation,” Harvard Business Review 81, no. 10 (2003): 82-91. 
${ }^{23}$ See, for example, Robert Axelrod, The Evolution of Cooperation (New York, 1984); Ernst

Fehr and Simon Gachter, "Fairness and Retaliation: The Economics of Reciprocity," The Journal of Economic Perspectives 14, no. 3 (2000): 159-81; Simon Gächter and Benedikt Herrmann, "Reciprocity, Culture and Human Cooperation: Previous Insights and a New Cross-Cultural Experiment, Philosophical Transactions of the Royal Society B 364, no. 1518 (2009): 791-806.

${ }^{24}$ Avner Greif, "Cultural Beliefs and the Organization of Society: A Historical and Theoretical Reflection on Collectivist and Individualist Societies," Journal of Political Economy 102, no. 5 (1994): 912-50; Avner Greif, “The Fundamental Problem of Exchange: A Research Agenda in Historical Institutional Analysis," European Review of Economic History 4 (2000) 251-84.

${ }^{25}$ Sherwin Rosen, “Implicit Contracts: A Survey,” Journal of Economic Perspectives 23, no. 3 (1985): 1144-75, here p. 1145; Costas Azariadis and Joseph E. Stiglitz, "Implicit Contracts and Fixed Price Equilibria," Quarterly Journal of Economics 98, Supplement (1983): 1-22.

${ }^{26}$ Elke Renner and Jean-Robert Tyran, "Price Rigidity in Customer Markets” Journal of Economic Behaviour and Organization 55, no. 4 (2004): 575-93.

${ }^{27}$ Okun, Prices and Quantities, 154.

${ }^{28}$ See Andrew T. Young and Daniel Levy, "Explicit Evidence on an Implicit Contract,” June 21, 2010, Emory Law and Economics Research Paper No. 4-05 and Bar Ilan Univ. Pub Law Working Paper No. 8-05, http://dx.doi.org/10.2139/ssrn.739984; Andrew Godley, "Pioneering Foreign Direct Investment in British Manufacturing," Business History Review 73, no. 3 (1999): 394-29; Andrew Godley, "The Global Diffusion of the Sewing Machine, 1850-1914," Research in Economic History 20 (2001): 1-45; Andrew Godley, "Selling the Sewing Machine around the World: Singer's International Marketing Strategies, 1850-1920," Enterprise and Society 7, no. 2 (2006): 266-314. 
${ }^{29}$ Godley, "Entrepreneurial Opportunities."

${ }^{30}$ In principle the costs of pre-sales demonstration could also be passed on to consumers in the same manner. But the obvious desire of producers to induce the transaction here obscures the same logic.

${ }^{31}$ And following on from the previous note, the same logic applies in principle to pre-sales demonstration services, but is likely to be obscured in practice. 